\title{
Plastic Mulch Color Inconsistently Affects Yield and Earliness of Tomato
}

\author{
James E. Brown', William D. Goff' ${ }^{1}$, James M. Dangler', \\ Walter Hogue ${ }^{2}$, and Mark S. West ${ }^{3}$ \\ Alabama Agricultural Experiment Station, Auburn University, AL 36849
}

Additional index words. Lycopersicon esculentum, photoselectivity

The surface color of plastic mulch can change the quantity of light and spectral balance reaching plants, with resulting effects on growth and fruit production (Decoteau et al., 1986, 1988, 1989). In their work with tomatoes (Lycopersicon esculentum Mill.), plants grown over red mulch had the highest early marketable yields and produced the least amount of foliage, while plants grown over white or silver-colored mulch had lower early marketable yields but produced more foliage. Since this research showed that mulch surface color may affect tomato production, we designed an experiment aimed to corroborate their results in another location and to expand the range of plastic mulch colors evaluated.

Field plots evaluating mulch color effects on fresh-market tomatoes were established at the E.V. Smith Research Center of Auburn Univ. in east-central Alabama in 1990. The soil was an Orangeburg sandy loam, a fineloamy siliceous thermic Typic Kandiudult. Lime and fertilizer were broadcast before planting and disked into the top $0.2 \mathrm{~m}$ of soil at rates determined by soil test recommendations for tomatoes (Cope et al., 1980).

Mulch treatments consisted of a bare soil unmulched control and seven colors of plastic mulch. For mulches where colors were obtained by painting, paints specified were diluted 2:1 with mineral spirits paint thinner and were sprayed onto standard black film (Edison Plastics Co., Washington, Ga.). The films listed, unless noted, were $31.5 \mu \mathrm{m}$ thick. Green: IRT-76 green wavelength-selective film (AEP Industries, Bonita Springs, Fla.). Aluminum: Painted with "aluminum 32" polyurethane oil enamel paint (Thompson and Formby, Memphis, Tenn.). Red: Painted with "Chinese red 15" polyurethane oil enamel paint (Thompson and Formby). Brown: 20.3-

Received for publication 2 Dec. 1991. Accepted for publication 10 June 1992. Alabama Agricultural Experiment Station Journal Series no. 11913194. We thank Brandon Early and Leslie Brasher for their assistance with this experiment. The cost of publishing this paper was defrayed in part by the payment of page charges. Under postal regulations, this paper therefore must be hereby marked advertisement solely to indicate this fact. 'Dept. of Horticulture.

E.V. Smith Research Center.

${ }^{3}$ Dept. of Research Data Analysis. $\mu \mathrm{m}$ brown wavelength-selective film (AEP). Clear: clear embossed polyethylene film (Tredegar Film Products, Richmond, Va.). Black: standard black film (Edison). White: white film (Edison).

The polyethylene mulches were $1.5 \mathrm{~m}$ wide and covered beds $0.8 \mathrm{~m}$ wide and $0.1 \mathrm{~m}$ high. Trickle irrigation tubing and methyl bromide fumigation were applied in all plots by a mulch layer applicator. Treatments were the seven colors of mulch plus an unmulched control. These eight treatments were arranged in a randomized complete block design with four replications. Experimental units were plots $7.6 \mathrm{~m}$ long with rows $1.5 \mathrm{~m}$ apart. 'Mountain Pride' tomato plants were started in a greenhouse on 5 Mar. and were transplanted to the field on $25 \mathrm{Apr}$. 1990. In-row plant spacing was $51 \mathrm{~cm}$. General cultural practices were in accordance with established recommendations for Alabama (Turner et al., 1988).

Fruit was harvested at the breaker color stage (Fahey, 1976) from plants in the center $6.1 \mathrm{~m}$ of row. Harvests were on 3, 5, 9, 16, and 20 July. After the last harvest, a portion of the plants was infested with southern blight (Sclerotium rolfsii Sacc.), and hatvesting was discontinued. Marketable yield consisted of fruit graded U.S. no. 1 or U.S. no. 2 (U.S. Dept. of Agriculture, 1976). Yields, by weight and fruit count, were calculated for marketable and unmarketable fruit for each harvest date. Season totals were calculated, and yields and percentages of fruit harvested early (first two harvests) were determined. Average weight of fruit was determined. All data were

Table 1. Plastic mulch color effects on yield and early harvest of tomatoes.

\begin{tabular}{|c|c|c|c|}
\hline \multirow[b]{2}{*}{ Color } & \multicolumn{2}{|c|}{$\begin{array}{l}\text { Marketable fruit } \\
\text { yield }\left(\mathrm{Mg}^{-} \mathrm{ha}^{-1}\right)\end{array}$} & \multirow{2}{*}{$\begin{array}{l}\text { Percent } \\
\text { harvested } \\
\text { early }\end{array}$} \\
\hline & Earlyz & Total & \\
\hline $\begin{array}{l}\text { Green } \\
\text { Aluminum } \\
\text { Red } \\
\text { Brown } \\
\text { Clear } \\
\text { Black } \\
\text { White } \\
\text { Unmulched }\end{array}$ & $\begin{array}{l}3.3 \mathrm{ab}^{\mathrm{y}} \\
4.7 \mathrm{a} \\
4.5 \mathrm{a} \\
3.8 \mathrm{ab} \\
3.9 \mathrm{ab} \\
4.3 \mathrm{a} \\
2.3 \mathrm{~b} \\
3.1 \mathrm{ab}\end{array}$ & $\begin{array}{c}18.7 \mathrm{a} \\
17.3 \mathrm{a} \\
13.0 \mathrm{ab} \\
13.6 \mathrm{ab} \\
12.4 \mathrm{ab} \\
8.7 \mathrm{~b} \\
8.0 \mathrm{~b} \\
13.8 \mathrm{ab}\end{array}$ & $\begin{array}{l}19 \mathrm{~b} \\
27 \mathrm{~b} \\
36 \mathrm{ab} \\
25 \mathrm{~b} \\
38 \mathrm{ab} \\
55 \mathrm{a} \\
34 \mathrm{ab} \\
22 \mathrm{~b}\end{array}$ \\
\hline
\end{tabular}

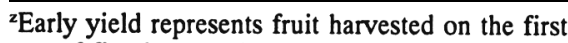
two of five harvest dates.

'Mean separation in columns by Duncan's multiple range test, $P=0.05$. tested by analysis of variance and by Duncan's multiple range test (SAS, 1988).

Early marketable yields were higher from plants grown over aluminum, red, or black mulch than from those grown over white mulch (Table 1). Total marketable yields for the season were higher from plants grown over green or aluminum mulch than from plants grown over black or white mulch, while unmulched plants and plants grown over mulches of other colors (red, brown, clear) produced intermediate yields. A higher percentage of fruit was harvested early (first two of five harvests) from plants grown over black plastic mulch than from unmulched plants or from plants grown over aluminum, brown, or green mulch, but total yield was low with black plastic. Mean weight per fruit was not significantly affected by treatment on any harvest date, nor were season means for fruit weight different among treatments (data not shown).

Reflective mulches had no advantage over unmulched or clear plastic mulch in either early or total yields. Examining our results and those of DeCoteau et al. (1989) suggests that reflective mulches do not consistently influence yield in tomato. Effects of various mulches on soil temperature, which we did not examine but which has been studied by others (Decoteau et al., 1989; Schalk and Robbins, 1987; Taber, 1983), may explain at least part of the yield differences we observed.

\section{Literature Cited}

Cope, J.T., C.E. Evans, and H.C. Williams. 1980. Soil test fertilizer recommendations for .Alabama crops. Ala. Agr. Expt. Sta. Circ. 251. Auburn Univ.

Decoteau, D.R., D.D. Daniels, M.J. Kasperbauer, and P.G. Hunt. 1986. Colored plastic mulches and tomato morphogenesis. Proc. Natl. Agr. Plastics Congr. 19:240-248.

Decoteau, D.R., M.J. Kasperbauer, D.D. Daniels, and P.G. Hunt. 1988. Plastic mulch color effects on reflected light and tomato plant growth. Scientia Hort. 34:169-175.

Decoteau, D.R., M.J. Kasperbauer, and P.G. Hunt. 1989. Mulch surface color affects yield of freshmarket tomatoes. J. Amer. Soc. Hort. Sci. 114(2):2x-219.

Fahey, J.V. 1976. How fresh tomatoes are marketed. U.S. Dept. Agr., Mktg. Serv., Mktg. Bul. 59.

SAS Institute, Inc. 1988. SAS/STAT user's guide: Release 6.03 ed. SAS Institute, Cary, N.C.

Schalk, J.M. and M.L. Robbins. 1987. Reflective film mulches influence plant survival, production, and insect control in fall tomatoes. HortScience 22:30-32.

Taber, H.G. 1983. Effects of plastic soil and plant covers on Iowa tomato and muskmelon production. Proc. Natl. Agr. Plastics Conf. 17:3745.

Turner, J., M. Patterson, W.S. Gazaway, S. Brown, and J.L. Williams. 1988. Commercial tomato production. Circ. ANR-145. Ala. Coop. Ext. Serv.

U.S. Department of Agriculture. 1976. U.S. standards for grades of fresh tomatoes. U.S. Dept. Agr., Mktg. Serv., Washington, D.C. 